\title{
Program til DUDS årsmøde 2021
}

Dato: 15. oktober 2021

Sted: Auditorium 1, Rigshospitalet

9.00-9.30 Ankomst kaffe

9.30-9:35 Velkomst (Tobias Todsen) 9:35-10.15 Key note speaker: Contrastenhanced ultrasound and microflow imaging (Professor Adrian Lim, Imperial College London)

10.15-10:30 Introduktion af industrien

\section{0:30-11:00 Kaffe og hands-on med industrien}

11.00-11:30 Kardiologisk ultralyd (Tor Biering-Sørensen)

11.30-12.00 Brug af kontrast og 3D ultralyd til karkirurgisk diagnostik (Jonas Peter Eiberg)

12.00-12.30 Doppler ultralyd i reumatologien (Lene Terslev)

\subsection{0-13.00 Frokost}

13.00-13.30 Ultralydsdiagnostik af nyrecyster (Ole Graumann)

13.30-14.00 Endoskopisk ultralyd til pankreas diagnostik (Peter Vilmann) 4.00-14.30 Fremtidens ultralyd (Jørgen Arendt Jensen)

\subsection{0-15.00 Kaffe og hands-on med} industrien

Eftermiddags tema: Frie foredrag og uddannelse i ultralyd

15.00-16.00 Frie foredrag

16.00-17.00 Uddannelse i ultralyd

- 14.00-14.15 Ultralyd i almen praksis (Thomas Løkkegaard)

- 14.15-14.30 Uddannelse og certificering i ultralyd (Martin Tolsgaard)

- 14:30-15.00 Plenary: Hvordan sikres kompetence i klinisk ultralyd?
Moderator Peter Thielsen, formand DUDS ekspert panel: Martin Tolsgaard, Thomas Løkkegaard, Lasse Bremholm og Thomas Vejborg

17.00-17.05 Afslutning og kåring af vinder af frie foredrag

17.15-18.00 DUDS general forsamling 18.30 Middag for DUDS medlemmer (FOOD CLUB Nørrebro)

Deltagelse i årsmødet er gratis men der kræves tilmelding ved at sende mail til dud stilmelding@gmail.com senest den 15. september.

Bemærk årsmødet er udsat fra foråret grundet corona. 